\title{
Differential pulse voltammetric determination of diclofenac in pharmaceutical preparations and human serum
}

\author{
Bilal Yilmaz", Selcuk Kaban, Bilge Kagan Akcay, Ulvihan Ciltas \\ Department of Analytical Chemistry, Faculty of Pharmacy, Ataturk University, Erzurum, Turkey
}

\begin{abstract}
This article describes a differential pulse voltammetric (DPV) method for the determination of diclofenac in pharmaceutical preparations and human serum. The proposed method was based on electro-oxidation of diclofenac at platinum electrode in $0.1 \mathrm{M} \mathrm{TBAClO}_{4} /$ acetonitrile solution. The well-defined two oxidation peaks were observed at 0.87 and $1.27 \mathrm{~V}$, respectively. Calibration curves that obtained by using current values measured for second peak were linear over the concentration range of 1.5-17.5 $\mu \mathrm{g}$ $\mathrm{mL}^{-1}$ and 2-20 $\mu \mathrm{g} \mathrm{mL}^{-1}$ in supporting electrolyte and serum, respectively. Precision and accuracy were also checked in all media. Intra- and inter-day precision values for diclofenac were less than 3.87, and accuracy (relative error) was better than $4.12 \%$. The method developed in this study is accurate, precise and can be easily applied to Diclomec, Dicloflam and Voltaren tablets as pharmaceutical preparation. In addition, the proposed technique was successfully applied to spiked human serum samples. No electroactive interferences from the endogenous substances were found in human serum.
\end{abstract}

Uniterms: Diclofenac/determination. Differential pulse voltammetry/quantitative analysis. Pharmaceutical formulations/analysis. Human serum/analysis

\begin{abstract}
Este artigo descreve um método de voltametria de pulso diferencial (VPD) para a determinação de diclofenaco em preparações farmacêuticas e em soro humano. O método proposto foi baseado em eletroxidação de diclofenaco no eléctrodo de platina em solução $0,1 \mathrm{M} \mathrm{TBAClO}_{4}$ /acetonitrila. Dois picos de oxidação bem definidos foram observados em 0,87 e 1,27 V, respectivamente. As curvas de calibração obtidas utilizando-se valores de corrente medidos por segundo pico foram lineares no intervalo de concentração de 1,5-17,5 $\mu \mathrm{g} \mathrm{mL}^{-1}$ e 2-20 $\mu \mathrm{g} \mathrm{mL} \mathrm{mL}^{-1}$ em eletrólito suporte e soro, respectivamente. Precisão e exatidão também foram verificadas em todos os meios. Valores de precisão intra- e inter-dia para o diclofenaco foram inferiores a 3.87 e a precisão (erro relativo) foi melhor do que $4,12 \%$. O método desenvolvido neste estudo é exato, preciso e pode ser facilmente aplicado a Diclomec, Dicloflam e comprimidos Voltaren, como preparação farmacêutica. Além disso, a técnica proposta foi aplicada com sucesso em amostras de soro humano. Não se observaram interferências das substâncias endógenas no soro humano.
\end{abstract}

Unitermos: Diclofenaco/determinação. Voltametria de pulso diferencial/análise quantitativa. Formulações farmacêuticas/análise. Soro humano/análise.

\section{INTRODUCTION}

Diclofenac (Figure 1), [o-(2,6-dichloroanilino) phenyl] acetate), is a non-steroidal anti-inflammatory drug (NSAID) with strong anti-pyretic, analgesic and antiinflammatory properties (Iliiescu, Baia, Miclaus, 2004).

\footnotetext{
Correspondence: B. Yilmaz. Department of Analytical Chemistry. Faculty of Pharmacy. Ataturk University. 25240 - Erzurum, Turkey. E-mail: yilmazb@atauni.edu.tr
}

It is widely used in clinical medicine for the treatment of inflammatory conditions such as rheumatoid arthritis, osteoarthritis and ankylosing spondylitis (Gostick et al., 1990; Crowley et al., 1990). The efficacy of diclofenac equals that of many newer and established NSAIDs. As an analgesic, it has a fast onset and a long duration of action. Compared to other NSAIDs, diclofenac is well tolerated and rarely produces gastrointestinal ulcerations or other serious side effects. Thus, diclofenac can be considered as one of few non-steroidal anti-inflammatory drugs of first 


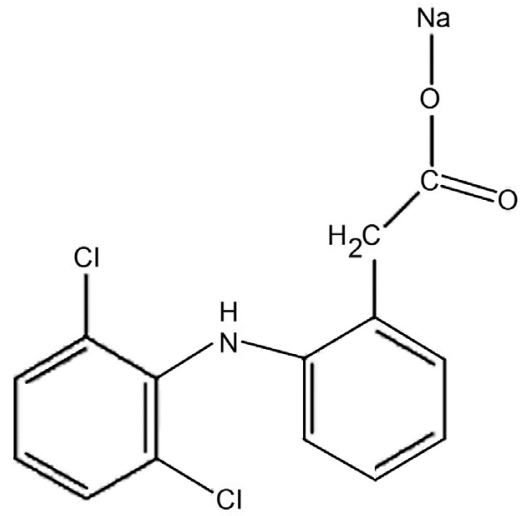

FIGURE 1 - Chemical structure of sodium diclofenac.

choice used in the treatment of acute and chronic, painful and inflammatory conditions (Roskar, Kmetec, 2003).

To date, several methods for the determination of diclofenac have been reported. These include potentiometry (Shamsipur, Jalali, Ershad, 2005; Santini, Pezza, Pezza, 2006; Hassan et al., 2005), capillary zone electrophoresis (Jin, Zhang, 2000), high performance liquid chromatography (HPLC) (González, Yuln, Volonté, 1999; Kasperek, 2008; Arcelloni et al., 2001), highperformance liquid chromatography-mass spectrometry (HPLC-MS) (Abdel-Hamid, Novotny, Hamza, 1990), spectrophotometry (Botello, Perez-Caballero, 1995), spectrofluorometry (Arancibia, Boldrini, Escandar, 2000; Damiani et al., 1999; Carreira et al., 1995), thin layer chromatography (Sun, Fabre, 1994), gas chromatography (Siou, Pommier, Godbillon, 1991; Yilmaz, 2010), polarographic analysis (Xu, Chen, Song, 2004), spectrophotometry (De Souza, Tubino, 2005; AgatonovicKustrin et al., 1997; Matin, Farajzadeh, Joyuban, 2005; Sastry, Prasad-Tipirneni, Suryanarayana, 1989; Sena et al., 2004) and electrochemistry methods (Blanco-Lopez et al., 2003; Goyal, Chatterjee, Agrawal, 2010; Manea et al., 2010). In all electrochemical methods, modified electrodes were used due to the gradual passivation or contamination of unmodified solid working electrodes occurred during the diclofenac oxidation. The development of modified electrodes is certainly one of the most extensive areas of research in analytical chemistry. However, it should be emphasized that electrode modification is frequently considered tedious and laborious process that can limit the use of these types of electrodes in routine analysis. Carbon-paste electrodes, due to their ease of construction, renewability and compatibility with various types of modifiers, have been widely used as a suitable matrix for the preparation of modified electrodes. Further, they show rather low background current compared to solid graphite or noble metal electrodes (Valentini et al., 2003).
In recent years, applications of carbon nanotube modified carbon paste electrodes have provided considerable improvements in the electrochemical behaviour of biologically important compounds (Antiochia et al., 2004; Norouzi et al., 2007). Metal nanowires such as dysprosium showed behaviour like carbon nanotubes. A carbonpaste electrode containing $10 \%(\mathrm{w} / \mathrm{w})$ of dysprosium nanowire/carbon paste electrode, in comparison with carbon-paste electrodes without nanowire, showed a very effective catalytic activity in the electrochemical oxidation of diclofenac. The reported methods were influenced by interference of endogenous substances and potential loss of drugs in the re-extraction procedure and involving lengthy, tedious and time-consuming plasma sample preparation and extraction processes requiring a sophisticated and expensive instrumentation.

The development of a new method capable of determining the drug amount in pharmaceutical dosage forms is important. Electro-analytical techniques have been used for the determination of a wide range of drug compounds with the advantages that there are, in most, instances no need for derivatization and that these techniques are less sensitive to matrix effects than other analytical techniques. Additionally, application of electrochemistry includes the determination of electrode mechanism. Redox properties of drugs can give insights into their metabolic fate or their in vivo redox processes or pharmacological activity (Kissenger, Heineman, 1996; Kauffmann, Vire, 1993; Ozkan, Uslu, Senturk, 2004). Despite the analytical importance of the electrochemical behaviour and oxidation mechanism of diclofenac, no report has been published on the voltammetric study of the electrochemical oxidation of diclofenac in non-aqueous media. Diclofenac is not soluble in water. It can be dissolved in water containing $30 \%$ methanol. Methanol has a narrow potential range. Therefore, it was dissolved in acetonitrile which had wide potential range.

It is well known that the experimental and instrumental parameters directly affect the electrochemical process and voltammetric response of drugs. Consequently, it would be interesting to investigate the oxidation process of diclofenac in aprotic media. Therefore, the goal of this work was the development of new DPV method for the direct determination of diclofenac in pharmaceutical preparations and spiked human serum samples without any time-consuming extraction or evaporation steps prior to drug assay. This paper describes fully validated, simple, rapid, selective and sensitive procedures for the determination of diclofenac employing DPV at the platinum disc electrode. Besides, the proposed method 
might be an alternative to the chromatographic methods in therapeutic drug monitoring.

\section{MATERIAL AND METHODS}

\section{Chemicals and reagents}

Diclofenac was obtained from Sigma (St. Louis, MO, USA). Acetonitrile (Fluka for HPLC analysis) was purified by drying with calcium hydride, followed by distillation from phosphorus pentoxide. Tetrabutylammonium perchlorate $\left(\mathrm{TBAClO}_{4}\right)$ were purchased from Fluka and used as received without further purification. Diclomec, Dicloflam and Voltaren tablets were obtained from pharmacy (Erzurum, Turkey). Human serum was obtained from Yakutiye blood bank, Erzurum, Turkey.

\section{Electrochemical instrumentation}

Electrochemical experiments were performed on a Gamry Potentiostat Interface 1000 controlled with software PHE 200 and PV 220. All measurements were carried out in a single-compartment electrochemical cell with a standard three-electrode arrangement. A platinum disk with an area of $0.72 \mathrm{~cm}^{2}$ and a platinum wire were used as the working and the counter electrodes, respectively. The working electrode was successively polished with $1.0,0.3$ and $0.05 \mu \mathrm{m}$ alumina slurries (Buehler) on microcloth pads (Buehler). After each polishing, the electrode was washed with water and sonicated for 10 min in acetonitrile. Then, it was immersed into a hot piranha solution $\left(3: 1, \mathrm{H}_{2} \mathrm{SO}_{4}, 30 \% \mathrm{H}_{2} \mathrm{O}_{2}\right)$ for $10 \mathrm{~min}$, and rinsed copiously with water. All potentials were reported versus $\mathrm{Ag} / \mathrm{AgCl} / \mathrm{KCl}(3.0 \mathrm{M})$ reference electrode (BAS Model MF-2078) at room temperature. The electrolyte solutions were degassed with purified nitrogen for 10 min before each experiment and bubbled with nitrogen during the experiment. Operating conditions for DPV were pulse amplitude $50 \mathrm{mV}$, pulse width $50 \mathrm{~ms}$ and scan rate $20 \mathrm{mV} \mathrm{s}^{-1}$.

\section{Preparation of the standard and quality control solutions}

The stock standard solution of diclofenac was prepared in $0.1 \mathrm{M} \mathrm{TBAClO}_{4}$ /acetonitrile to a concentration of $100 \mu \mathrm{g} \mathrm{mL}^{-1}$ and stored at $4{ }^{\circ} \mathrm{C}$. Working standard solutions were prepared from the stock solution. A calibration graph was constructed in the range of $1.5,2.5$, $5,7.5,10,12.5,15$ and $17.5 \mu \mathrm{g} \mathrm{mL}^{-1}$ for diclofenac $(\mathrm{n}=6)$.
For quality control (QC) samples containing concentration 4,8 and $16 \mu \mathrm{g} \mathrm{mL}^{-1}$ of diclofenac, the stock solution was diluted with $0.1 \mathrm{M} \mathrm{TBAClO}_{4} /$ acetonitrile.

\section{Procedure for pharmaceutical preparations}

A total 10 tablets of diclofenac (Diclomec, Dicloflam and Voltaren) were accurately weighed and powdered. An amount of this powder corresponding to one tablet diclofenac content was weighed and accurately transferred into $100 \mathrm{~mL}$ calibrated flask and $50 \mathrm{~mL}$ of $0.1 \mathrm{MTBAClO}_{4} /$ acetonitrile was added and then the flask was sonicated to $10 \mathrm{~min}$ at room temperature. The flask was filled to volume with $0.1 \mathrm{M} \mathrm{TBAClO}_{4}$ /acetonitrile. The resulting solutions in both cases were filtered through Whatman filter paper no 42 and suitably diluted to get final concentration within the limits of linearity for the respective proposed method. The drug content of diclofenac tablets was calculated from the current potential curve.

\section{Recovery studies}

To study the accuracy and reproducibility of the proposed technique, recovery experiments were carried out using the standard addition method. In order to know whether the excipients show any interference with the analysis, known amounts of pure diclofenac were added to the pre-analysed tablet formulation and the mixtures were analysed by the proposed method. After five repeated experiments, the recovery results were calculated using the calibration equation.

\section{Analysis of spiked serum samples}

Drug-free human blood, obtained from healthy volunteers (after obtaining their written consent), was centrifuged (5000 rpm) for $30 \mathrm{~min}$ at room temperature and separated serum samples were stored frozen until assay. An aliquot volume of serum sample was fortified with diclofenac dissolved in acetonitrile to achieve final concentration of $100 \mu \mathrm{g} \mathrm{mL}^{-1}$. Acetonitrile removes serum proteins more effectively, as the addition of $1.0 \mathrm{~mL}$ volume of serum is sufficient to remove the proteins. After vortexing for $30 \mathrm{~s}$, the mixture was then centrifuged for $5 \mathrm{~min}$ at $5000 \mathrm{rpm}$ for getting rid of serum protein residues and the supernatant was taken carefully. Appropriate volumes of this supernatant were transferred into the volumetric flask. The concentration of diclofenac was varied in the range of 2-20 $\mu \mathrm{g} \mathrm{mL}^{-1}$ in human serum samples. Quantifications were performed by means of calibration curve method from the related calibration equation. 


\section{RESULTS AND DISCUSSION}

\section{Voltammetric behaviour of diclofenac}

The electrochemical behaviour of diclofenac was investigated at the Pt disc electrode in anhydrous acetonitrile solution containing $0.1 \mathrm{M} \mathrm{TBAClO}_{4}$ as the supporting electrolyte by using cyclic voltammetry (CV). Figure 2 shows a typical cyclic voltammogram of $20 \mu \mathrm{g} \mathrm{mL}^{-1}$ diclofenac recorded under these conditions for the scan rate of $0.2 \mathrm{~V} \mathrm{~s}^{-1}$. In the anodic sweep, two oxidation peaks are seen at about the potentials of 0.87 and $1.27 \mathrm{~V}$, respectively.

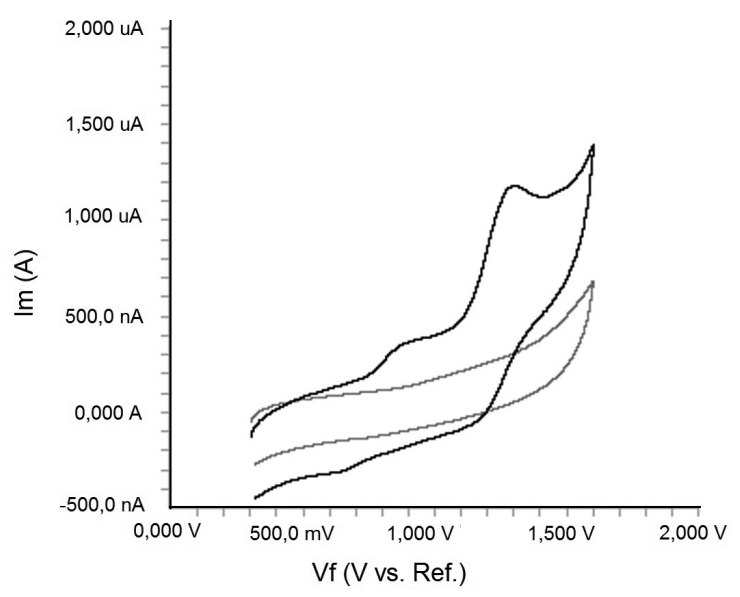

FIGURE 2 - Cyclic voltammogram for the oxidation of $20 \mu \mathrm{g} \mathrm{mL}^{-1}$ diclofenac in acetonitrile containing $0.1 \mathrm{M} \mathrm{TBAClO}_{4}$ at Pt disk electrode, scan rate: $0.2 \mathrm{~V} \mathrm{~s}^{-1}$.

In order to gain a deeper insight into the voltammetric waves, the effect of scan rate on the anodic peak currents ( $I$ ) and peak potentials (E) was studied in the range of $0.01-1 \mathrm{~V} \mathrm{~s}^{-1}$ of the potential scan rates in acetonitrile solution containing $20 \mu \mathrm{g} \mathrm{mL}^{-1}$ concentration of diclofenac (Figure 3).

The representative linear sweep voltammograms obtained at Pt electrode for $20 \mu \mathrm{g} \mathrm{mL}^{-1}$ diclofenac as a function of the scan rate are presented in Figure 4. Scan rate dependency experiments show that the peak currents vary linearly with the scan rate $(v)$ (Figures $4 a, b)$, which points out the adsorption-controlled process. However, the plots of logarithm of peak currents versus logarithm of scan rates for $20 \mu \mathrm{g} \mathrm{mL}^{-1}$ concentration of diclofenac display straight lines with 0.497 slope (Figure 4c), which are close to theoretical value of 0.5 expected for an ideal diffusion-controlled electrode process (Laviron, Roullier, Degrand, 1980).

$\log I-\log v$ curve is more eligible for this aim, therefore, a diffusional process for peak should be

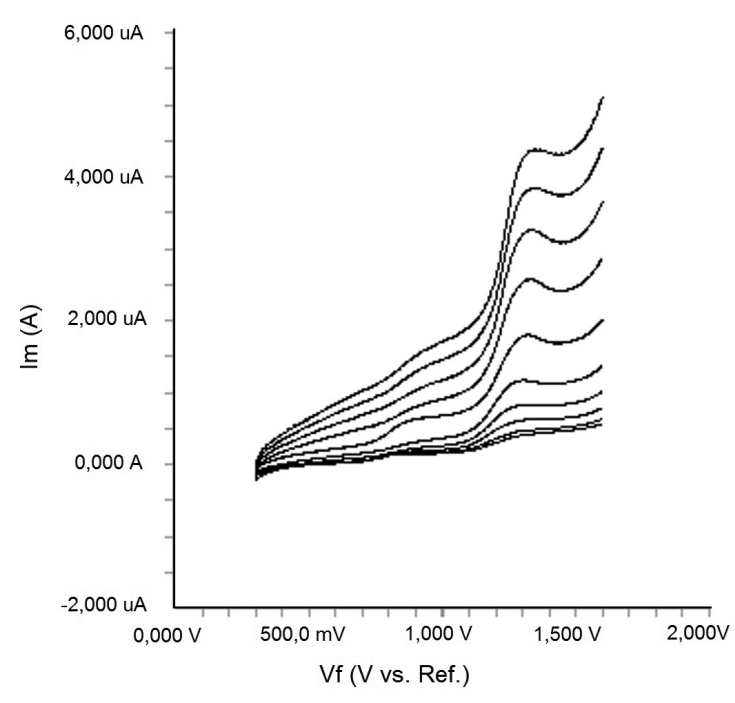

FIGURE 3 - Linear sweep voltammograms for the oxidation of $20 \mu \mathrm{g} \mathrm{mL}^{-1}$ diclofenac in acetonitrile containing $0.1 \mathrm{M} \mathrm{TBAClO}_{4}$ as a function of scan rate.

considered. These results suggest that the redox species are diffusing freely from solution and not precipitating onto the electrode surface. The reason for this behaviour may be due to the solubility of the intermediate species in acetonitrile or poor adherence of products on the electrode surface.

The oxidation peak potential (E) for the peaks shifts toward more positive values with increasing scan rate. The relationship between the peak potential and scan rate is described by the following equation,

$$
\begin{gathered}
E=E^{0^{\prime}}+R T /\left[(1-\alpha) n_{a} F\right]\left[0.78+\ln \left(D^{1 / 2} k_{s}^{-1}\right)-\right. \\
\left.0.5 \ln R T /\left[(1-\alpha) n_{a} F\right]\right]+R T /\left[(1-\alpha) n_{a} F\right] / 2 \ln v
\end{gathered}
$$

and from the variation of peak potential with scan rate $\alpha \mathrm{n}_{\mathrm{a}}$ can be determined, where $\alpha$ is the transfer coefficient and $n_{a}$ is the number of electrons transferred in the rate determining step. According to this equation, the plots of the peak potentials versus $\ln v$ for the oxidation peak show linear relationship. The slope indicates the value of $\alpha \mathrm{n}_{\mathrm{a}}$ is 0.38 for peak. On the basis of above results, $\mathrm{n}_{\mathrm{a}}$ is 1 then the value of $\alpha$ is calculated as 0.38 , which is reasonable for most irreversible electrode processes. Based on above discussions, the oxidation process of diclofenac is controlled by the diffusion step and one electron and one proton are involved in the reaction.

\section{Analytical applications and validation of the proposed method}

In order to develop a voltammetric procedure for the 

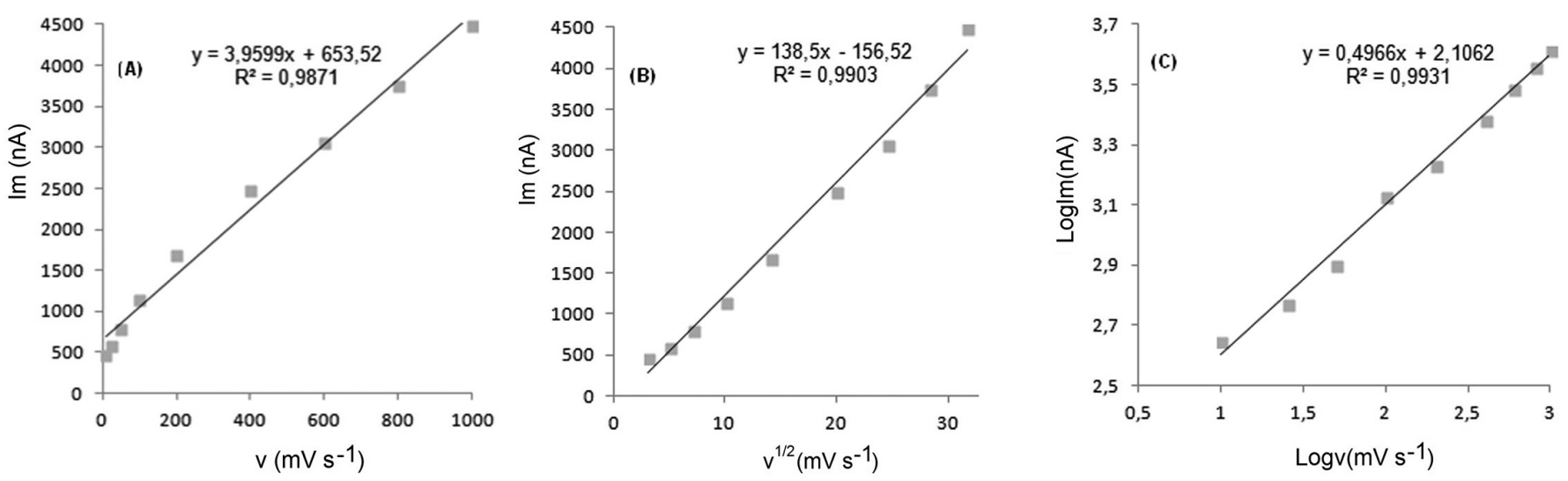

FIGURE 4 - A, B, C: Dependence of peak current on the scan rate $\left(20 \mu \mathrm{gL}^{-1}\right)$.

determination of drug, we selected the DPV technique, since the peaks were sharper and better defined at lower concentration of diclofenac than those obtained by cyclic and linear sweep voltammetry with a lower background current, resulting in improved resolution. DPV is an effective and rapid electro-analytical technique with wellestablished advantages, including good discrimination against background currents and low detection limits (Wang, 1996; Kissenger,Heineman, 1996).

Calibration graphs from the standard solution of diclofenac according to the procedures described above were constructed by using DPV. A linear relation in the concentration range between 1.5-17.5 $\mu \mathrm{g} \mathrm{mL}^{-1}$ was found, indicating that the response was diffusion controlled in this range (Figure 5).

Above this concentration $\left(17.5 \mu \mathrm{g} \mathrm{mL}^{-1}\right)$, a loss of linearity was probable due to the adsorption of diclofenac on the electrode surface. The characteristics of the calibration plots are summarized in Table I.

The precision of the DPV method was determined by repeatability (intra-day) and intermediate precision (inter-day). Repeatability was evaluated by analysing QC samples six times per day, at three different concentrations which were QC samples. The intermediate precision was evaluated by analysing the same samples once daily for two days. The RSD of the predicted concentrations from the regression equation was taken as precision. The accuracy of this analytic method was assessed as the percentage relative error. For all concentrations studied, intra- and inter-day relative standard deviation values were $\leq 3.87 \%$ and for all concentrations of diclofenac the relative errors were $\leq 4.12 \%$.

The limit of detection (LOD) and the limit of quantification (LOQ) were calculated on the peak current using the following equation:

$$
\mathrm{LOD}=3 \mathrm{~s} / \mathrm{m} ; \mathrm{LOQ}=10 \mathrm{~s} / \mathrm{m}
$$

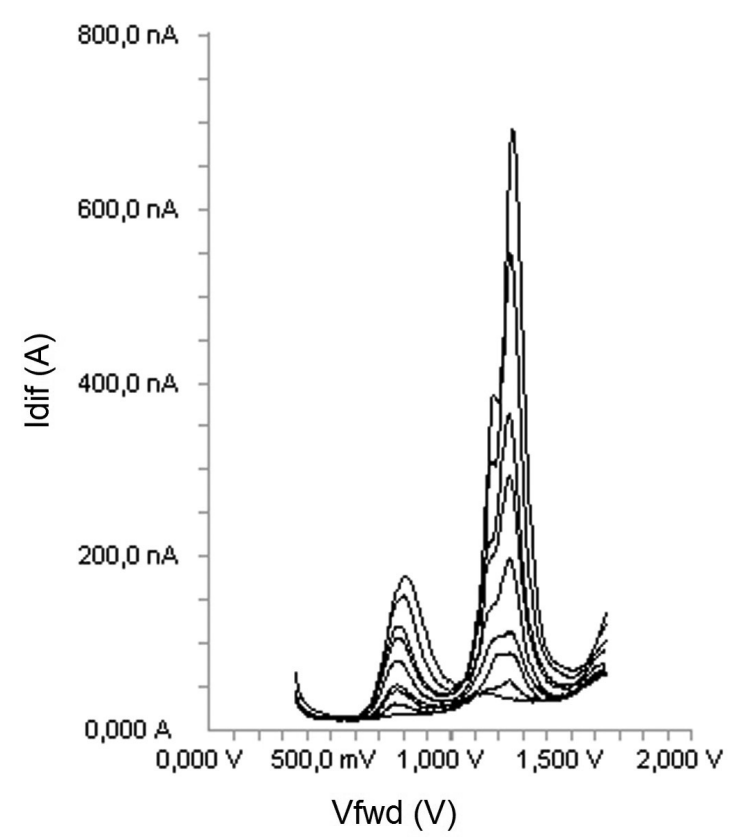

FIGURE 5 - DPV voltammograms obtained for determination in supporting electrolyte (blank, 1.5, 2.5, 5, 7.5, 10, 12.5, 15 and $17.5 \mu \mathrm{g} \mathrm{mL}^{-1}$ ).

where $\mathrm{s}$ is the standard deviation of the peak currents (three runs) and $\mathrm{m}$ is the slope of the calibration curve. The LOD and LOQ values were also shown in Table I. Repeating five experiments on $15 \mu \mathrm{g} \mathrm{mL} \mathrm{m}^{-1}$ diclofenac for DPV technique tested the repeatability and reproducibility of peak potential and peak currents. The results were shown also in Table I. Repetition of the sample analysis after $72 \mathrm{~h}$ period did not show any significant change in the results of the analyses.

\section{Determination of diclofenac in tablets}

On the basis of above results, DPV method was applied for the direct determination of diclofenac in 
TABLE I - Regression data of the calibration lines for the quantitative determination of diclofenac

\begin{tabular}{|c|c|c|}
\hline \multirow{2}{*}{ Parameters } & \multicolumn{2}{|c|}{ DPV } \\
\hline & Supporting electrolyte & Serum \\
\hline Measured potential (V) & 1.34 & 1.31 \\
\hline Linearity $\left(\mu \mathrm{g} \mathrm{mL}^{-1}\right)$ & $1.5-17.5$ & $2-20$ \\
\hline Slope & 6.7632 & 5.3249 \\
\hline Intercept & 27.26 & 32.67 \\
\hline $\mathrm{R}$ & 0.999 & 0.998 \\
\hline $\mathrm{Sa}$ & 9.48 & 12.42 \\
\hline $\mathrm{Sb}$ & 0.765 & 1.624 \\
\hline $\operatorname{LOD}\left(\mu \mathrm{g} \mathrm{mL} L^{-1}\right)$ & 0.30 & 0.60 \\
\hline LOQ $\left(\mu \mathrm{g} \mathrm{mL}^{-1}\right)$ & 0.90 & 1.80 \\
\hline Precision (RSD\%) & 2.96 & 3.87 \\
\hline Accuracy (\% relative error) & 3.46 & 4.12 \\
\hline Repeatability of peak current $(\mathrm{RSD} \%)^{\mathrm{a}}$ & 1.38 & 2.67 \\
\hline Repeatability of peak potential (RSD\%) & 1.94 & 2.46 \\
\hline Reproducibility of peak current (RSD\%) & 2.96 & 3.24 \\
\hline Reproducibility of peak potential (RSD\%) & 0.69 & 1.24 \\
\hline
\end{tabular}

RSD: Relative standard deviation, ${ }^{a}$ Average of six replicate determinations, Sa: Standard deviation of intercept of regression line, Sb: Standard deviation of regression line slope, R: Correlation coefficient, LOD: Limit of detection, LOQ: Limit of quantification

pharmaceutical preparations, using the related calibration straight lines without any sample extraction or filtration and after adequate dilutions. The results show that the proposed method was successfully applied for the assay of diclofenac in its pharmaceutical dosage forms (Table II). The accuracy of the method was determined by its recovery during spiked experiments. Recovery studies were carried out after the addition of known amounts of the pure drug to various pre-analysed formulation of diclofenac. According to the results, excipients presented in tablet do not interfere with the analysis (Table II).
There is no official method in any pharmacopoeias (e.g. USP, BP or EP) or literature method related to pharmaceutical dosage forms of diclofenac. To prove the absence of interferences by excipients, recovery studies were carried out. The results demonstrate the validity of the proposed method for the determination of diclofenac in tablets. These results reveal that both methods had adequate precision and accuracy and consequently can be applied to the determination of diclofenac in pharmaceuticals without any interference from the excipients.

Birajdar, Meyyanathan and Suresh (2010) developed

TABLE II - Recovery of the diclofenac in pharmaceutical preparations

\begin{tabular}{lccc}
\hline & Diclomec & Dicloflam & Voltaren \\
\hline Labelled claim $(\mathrm{mg})$ & 100 & 50 & 75 \\
Amount found $(\mathrm{mg})^{\mathrm{a}}$ & 99.4 & 50.2 & 75.4 \\
$\mathrm{RSD} \%$ & 2.43 & 1.84 & 2.73 \\
Bias\% & -0.60 & 0.40 & 0.53 \\
Added $\left(\mu \mathrm{g} \mathrm{mL}^{-1}\right)$ & 10 & 10 & 10 \\
Found $\left(\mu \mathrm{g} \mathrm{mL}^{-1}\right)$ & 9.94 & 10.04 & 10.09 \\
Recovery\% & 99.4 & 100.4 & 100.9 \\
RSD $\%$ of recovery & 2.52 & 1.92 & 2.32 \\
\hline
\end{tabular}

${ }^{a}$ Each value is the mean of five experiments 
a reverse phase HPLC method for the simultaneous determination of rabeprazole and diclofenac in tablet. The method was based on HPLC separation of both drugs in reverse phase mode using Phenomenox $\mathrm{C}_{18}$ column with Waters HPLC system by using mobile phase composition of acetonitrile and $50 \mathrm{mM}$ ammonium acetate buffer $(\mathrm{pH} 3.6)(60: 40 \mathrm{v} / \mathrm{v})$ at flow rate $1 \mathrm{~mL} \mathrm{~min}^{-1}$. Detection wavelength used at $254 \mathrm{~nm}$. Linearity was obtained in the concentration range of 1.0-3.2 $\mu \mathrm{g} \mathrm{mL}^{-1}$ for rabeprazole and 6.0-16.0 $\mu \mathrm{g} \mathrm{mL}^{-1}$ diclofenac.

Sastry, Prasad-Tipirneni and Suryanarayana (1989) described a spectrophotometric method for the determination of diclofenac sodium in bulk samples and pharmaceutical preparations with $p$ - $N, N$-dimethylphenylenediamine as solvent and maximum absorbance at $670 \mathrm{~nm}$. The reaction is sensitive enough to permit the determination of $2.0-24 \mu \mathrm{g} \mathrm{mL}^{-1}$.

Agrawal Shivramchandra (1991) described two methods for the determination of diclofenac. In the first method diclofenac reduces iron(III) to iron(II) having a maximum absorbance at $520 \mathrm{~nm}$. The reaction obeys Beer's law for the concentrations of $10-80 \mu \mathrm{g} \mathrm{mL}^{-1}$. In the second method, diclofenac is treated with methylene blue in the presence of phosphate buffer ( $\mathrm{pH}$ 6.8) and the complex is extracted with chloroform. The complex has a maximum absorbance at $640 \mathrm{~nm}$ and linearity was in the range $5-40 \mu \mathrm{g} \mathrm{mL}^{-1}$.

Thongchai et al. (2006) developed a high performance thin layer chromatographic method for the determination of diclofenac sodium in pharmaceutical formulations. The drug was extracted from the sample then various aliquots of this solution were spotted automatically by means of Camag Linomat IV on a silica gel 60 F254 aluminium plate, using a mixture of toluene: ethyl acetate: glacial acetic acid (60:40:1, v/v/v) as mobile phase. The spot areas were quantified by densitometry at $282 \mathrm{~nm}$. Linear calibration curve was obtained over the range 5-80 $\mu \mathrm{g} \mathrm{mL}^{-1}$.

For DPV measurements, calibration curve was linear over the concentration range of 1.5-17.5 $\mu \mathrm{g} \mathrm{mL}^{-1}$ for diclofenac, which is as good as or superior to that reported in other papers (Birajdar, Meyyanathan, Suresh, 2010; Sastry, Prasad-Tipirneni, Suryanarayana, 1989; Agrawal et al., 1991; Thongchai et al., 2006).

\section{Determination of diclofenac in human serum samples}

The optimized procedure was successfully applied for the determination of diclofenac in protein-free spiked human serum samples. Acetonitrile and methanol were tried as the serum precipitating agents. The best results were obtained with acetonitrile. Hence, acetonitrile was used for the following studies. The measurements of diclofenac in serum samples were performed as described in the analysis of spiked serum samples section. For the applicability of the proposed method to the human serum, the calibration equation was obtained in spiked human serum. Calibration equation parameters and validation data are shown in Table I. Obtained recovery results of spike human serum samples are given in Table III.

TABLE III - Recovery of diclofenac in human serum

\begin{tabular}{cccc}
\hline $\begin{array}{c}\text { Added } \\
\left(\boldsymbol{\mu} \mathbf{g} \mathbf{~ m}^{-1}\right)\end{array}$ & $\begin{array}{c}\text { Found } \\
\left(\mathbf{M e a n} \pm \mathbf{S D}^{\mathbf{a}}\right)\end{array}$ & \% Recovery & \% RSD $^{\mathbf{b}}$ \\
\hline 2 & $1.86 \pm 0.051$ & 93.0 & 2.74 \\
5 & $4.83 \pm 0.219$ & 96.6 & 4.53 \\
7.5 & $7.45 \pm 0.499$ & 99.3 & 6.69 \\
10 & $9.82 \pm 0.785$ & 98.2 & 7.99 \\
12.5 & $12.32 \pm 1.08$ & 98.6 & 8.77 \\
15 & $14.82 \pm 1.29$ & 98.8 & 8.70 \\
17.5 & $18.04 \pm 1.67$ & 103.7 & 9.25 \\
20 & $20.2 \pm 1.65$ & 101.0 & 8.17 \\
\hline
\end{tabular}

$\mathrm{SD}^{\mathrm{a}}$ : Standard deviation of six replicate determinations,

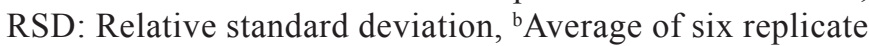
determinations

Using the proposed DPV technique, no sample pre-treatment was required other than precipitation and dilution steps. The recovery results of diclofenac (Table III) in serum samples were calculated from the related linear regression equations, which are given in Table I. Good recoveries of diclofenac were achieved from this type of matrix. Analysis of serum samples by DPV involved only protein precipitation and centrifugation, no time-consuming extraction and evaporation steps are required. In this study, the serum proteins and endogenous substances in serum samples are precipitated by the addition of acetonitrile, which is centrifuged at $5000 \mathrm{rpm}$, and the supernatant was taken and diluted with the supporting electrolyte and directly analysed. Typical DPV curve of diclofenac examined in serum samples are shown in Figure 6.

As can be seen in Figure 6, no oxidation compounds and no extra noise peaks present in biological material peak occurred in the potential range where the analytical peak appeared.

Stability of serum samples kept in refrigerator $\left(+4{ }^{\circ} \mathrm{C}\right)$ was tested by making five consecutive analyses of the sample over a period of approximately $5 \mathrm{~h}$. There were 


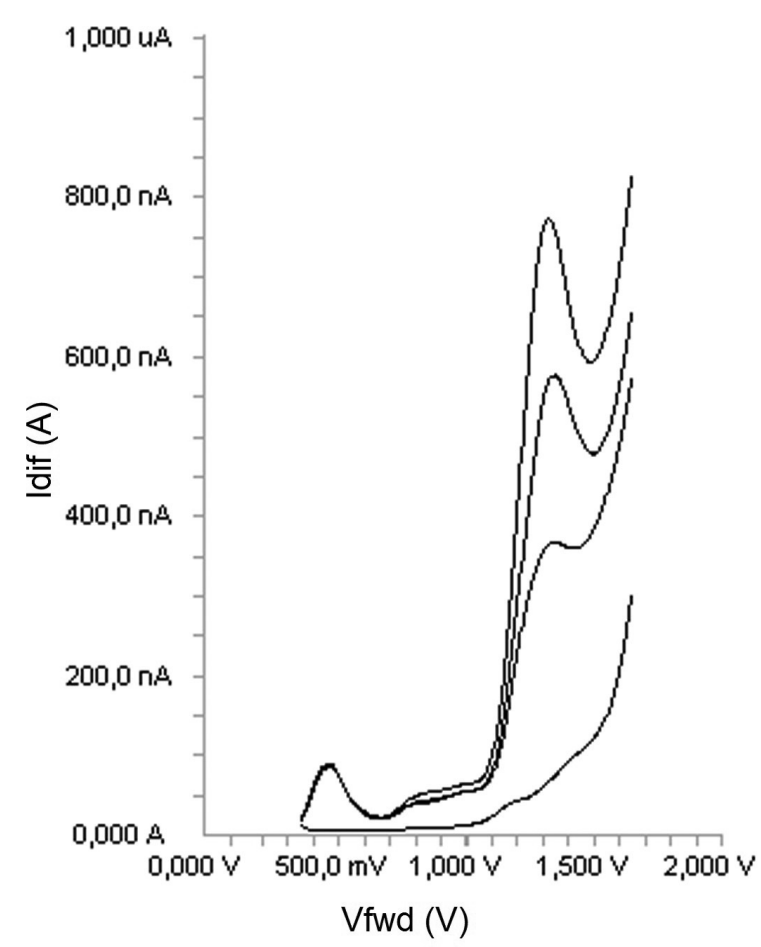

FIGURE 6 - DPV voltammograms obtained for the determination in spiked serum (blank, 5, 10 and $15 \mu \mathrm{g} \mathrm{mL}^{-1}$ ).

no significant changes in the peak currents and potentials between the first and last measurements.

\section{CONCLUSIONS}

In this work, a new DPV technique has been developed for the determination of diclofenac in pharmaceutical preparations and human serum samples. The results obtained show that the above-described methods are useful not only for diclofenac determination in conventional electrolytes, but also in more complex matrices such as dosage forms and human serum samples. The principal advantages of DPV technique over other techniques are that they may be applied directly to the analysis of pharmaceutical dosage forms and biological samples without the need for separation or complex sample preparation, since there was no interference from the excipients and endogenous substances. The method is rapid, requiring less than $5 \mathrm{~min}$ to run sample.

\section{ACKNOWLEDGEMENTS}

This study was supported by a Grant from Ataturk University Research Foundation (Project no: 2012/78). The authors have no conflicts of interest that are directly relevant to the content of this study.

\section{REFERENCES}

ABDEL-HAMID, M.E.; NOVOTNY, L.; HAMZA, H.J. Determination of diclofenac sodium, flufenamic acid, indomethacin and ketoprofen by LC-APCI-MS. Pharm. Biomed. Anal., v.24, p.587-594, 2001.

AGATONOVIC-KUSTRIN, S.; ZIVANOVIC, L.J.; ZECEVIC, M.; RADULOVIC, D. Spectrophotometric study of diclofenac-Fe(III) complex. J. Pharm. Biomed. Anal. v.16, p.147-153, 1997.

A G R A W A L, Y.K.; S H I V R A M C H A N D R A, K. Spectrophotometric determination of diclofenac sodium in tablets. J. Pharm. Biomed. Anal., v.9, p.97-100, 1991.

ANTIOCHIA, A.; LAVAGNINI, I.; MAGNO, F.; VALENTINI, F.; PALLESCHI, G. Single-wall carbon nanotube paste electrodes: a comparison with carbon paste, platinum and glassy carbon electrodes via cyclic voltammetric data. Electroanalysis, v.16, p.1451-1458, 2004.

ARANCIBIA, J.A.; BOLDRINI, M.A.; ESCANDAR, G.M. Spectrofluorimetric determination of diclofenac in the presence of alpha-cyclodextrin. Talanta, v.52, p.261-268, 2000.

ARCELLONI, C.; LANZI, R.; PEDERCINI, S.; MOLTENY, G. High-performance liquid chromatographic determination of diclofenac in human plasma after solid-phase extraction. $J$. Chromatogr., v.763, p.195-200, 2001.

BLANCO-LOPEZ, M.C.; LOBO-CASTANON, M.J.; MIRANDA-ORDIERES, A.J.; TUNON-BLANCO, p.Voltammetric response of diclofenac-molecularly imprinted film modified carbon electrodes. Anal. Bioanal. Chem., v.377, p.257-261, 2003.

BOTELLO, J.C.; PÉREZ-CABALLERO, G. Spectrophotometric determination of diclofenac sodium with methylene-blue. Talanta, v.42, p.105-108, 1995.

BIRAJDAR, A.S.; MEYYANATHAN, S.; SURESH, B. A RP-HPLC method for determination of diclofenac with rabeprazole in solid dosage form. Pharm. Sci. Monitor., v. 2 p.171-178, 2010. 
CARREIRA, L. A,; RIZK, M.; EL-SHABRAWY, Y.; ZAKHARI, n.A.; TOUBAR, S. S. Europium(III) ion probe spectrofluorometric determination of diclofenac sodium. $J$. Pharm. Biomed. Anal., v.13, p.331-1337, 1995.

\section{CROWLEY, B.; HAMILL, J.J.; LYNDON, S.; MCKELLICAN,} J.F.; WILLIAMS, P.; MILLER, A.J. Controlled-release indomethacin and sustained-release diclofenac sodium in the treatment of rheumatoid-arthritis - a comparative controlled clinical-trial. Curr. Med. Res. Opin., v.12, p.143$150,1990$.

DAMIANI, p.C.; BEARZOTTI, M.; CABEZON, M.A.; OLIVIERI, A.C. Spectrofluorometric determination of diclofenac in tablets and ointments. J. Pharm. Biomed., v.20, p.587-590, 1999.

DE SOUZA, R.L.; TUBINO, M. Spectrophotometric determination of diclofenac in pharmaceutical preparations. J. Brazil. Chem. Soc., v.16, p.1068-1073, 2005.

GONZÁLEZ, L., YULN, G., VOLONTÉ, M.G. Determination of cyanocobalamin, betamethasone, and diclofenac sodium in pharmaceutical formulations, by high performance liquid chromatography. J. Pharm. Biomed. Anal., v.20, p.487-492, 1999.

GOSTICK, N.; JAMES, I.G.; KHONG, T.K.; ROY, P.; SHEPHERD, P.R.; MILLER, A.J. Controlled-release indomethacin and sustained-release diclofenac sodium in the treatment of osteoarthritis - a comparative controlled clinical-trial in general-practice. Curr. Med. Res. Opin., v.12, p.135-142, 1990.

GOYAL, R.N.; CHATtERJEE, S.; AGRAWAL, B. Electrochemical investigations of diclofenac at edge plane pyrolytic graphite electrode and its determination in human urine. Sens. Actuators B, v.145, p.743-748, 2010.

HASSAN, S.S.M.; MAHMOUD, W.H.; ELMOSALLANY, M.A.F.; ALMAZZOOQI, M.H. Iron(II)- phthalocyanine as a novel recognition sensor for selective potentiometric determination of diclofenac and warfarin drugs. J. Pharm. Biomed., v.39, p.315-321, 2005.

ILIIESCU, T.; BAIA, M.; MICLAUS, v.A raman spectroscopic study of the diclofenac sodium-betacyclodextrin interaction. Eur. J. Pharm. Sci., v.22, p.487-495, 2004.
JIN, W.; ZHANG, J. Determination of diclofenac sodium by capillary zone electrophoresis with electrochemical detection. J. Chromatogr., v.868, p.101-107, 2000.

KAUFFMANN, J.M.; VIRE, J.C. Pharmaceutical and biomedical applications of electroanalysis. Anal. Chim. Acta, v.273, p.329-336, 1993.

KASPEREK, R. Determination of diclofenac sodium and papaverine hydrochloride in tablets by hplc method. Acta Poloniae Pharm., v.65, p.403-408, 2008.

KISSENGER, P.T.; HEINEMAN, W.R. (Eds.) Laboratory techniques in electroanalytical chemistry, second ed., New York: Marcel Dekker, 1996.

LAVIRON, E.; ROULLIER, L.; DEGRAND, C. A multilayer model for the study of space distributed redox modified electrodes. Theory and application of linear potential sweep voltammetry for a simple reaction. J. Electroanal Chem., v.112, p.11-23, 1980.

MANEA, F.; IHOS, M.; REMES, A.; BURTICA, G.; SCHOONMAN, J. Electrochemical determination of diclofenac sodium in aqueous solution on cu-doped zeoliteexpanded graphite-epoxy electrode. Electroanalysis, v.22, p.2058-2063, 2010.

MATIN A.A.; FARAJZADEH, M.A.; JOYUBAN, A. A simple spectrophotometric method for determination of sodium diclofenac in pharmaceutical formulations. Farmaco, v.60, p.855-861, 2005.

NOROUZI, P.; SHIRVANI-ARANI, S.; DANESHGAR, P.; GANJALI, M.R. Sub-second adsorptive fast fourier transform coulometric technique as a novel method for the determination of nanomolar concentrations of sodium valproate in its pharmaceutical preparation in flowing solution systems. Biosens. Bioelectron., v.22, p.1068-1074, 2007.

OZKAN, S.A.; USLU, B.; SENTURK, Z. Electroanalytical characteristics of amisulpride and voltammetric determination of the drug in pharmaceuticals and biological media. Electroanalysis, v.16, p.231-237, 2004.

ROSKAR, R.; KMETEC, v.Liquid chromatographic determination of diclofenac in human synovial fluid. $J$. Chromatogr. B., v.788, p.57-64, 2003. 
SANTINI A. O.; PEZZA, H. R.; PEZZA, L. Determination of diclofenac in pharmaceutical preparations using a potentiometric sensor immobilized in a graphite matrix. Talanta, v.68, p.636-642, 2006.

SASTRY, C.S.P.; PRASAD-TIPIRNENI, A.S.R.; SURYANARAYANA, M.V. Spectrophotometric analysis of some anthranilic acid-derivatives and their pharmaceutical preparations. Microchem. J., v.39, p.277-289, 1989.

SENA, M.M.; CHAUDHRY, Z.F.; COLLINS, C.H.; POPPI, R.J. $\mathrm{N}$-way PLS applied to simultaneous spectrophotometric determination of acetylsalicylic acid, paracetamol and caffeine. J. Pharm. Biomed. Anal., v.36, p.743-749, 2004.

SHAMSIPUR, M.; JALALI, F.; ERSHAD, S. Preparation of a diclofenac potentiometric sensor and its application to pharmaceutical analysis and to drug recovery from biological fluids. J. Pharm. Biomed., v.37, p.943-947, 2005.

SIOU, A.; POMMIER, F.; GODBILLON, J. Determination of diclofenac in plasma and urine by capillary gaschromatography mass-spectrometry with possible simultaneous determination of deuteriumlabeled diclofenac. J. Chromatogr., v.571, p.87-100, 1991.

SUN, S.W.; FABRE, H. Practical approach for validating the tlc assay of an active ingredient in a pharmaceutical formulation. J. Liq. Chromatogr., v.17, 433-445, 1994.
THONGCHAI, W.; LIAWRUANGRATH, B.; THONGPOON, C.; MACHAN, T. High performance thin layer chromatographic method for the determination of diclofenac sodium in pharmaceutical formulations. Chiang Mai J. Sci., v.33 p.123-128, 2006.

VALENTINI, F.; AMINE, A.; ORLANDOCCI, S.; TERRANOVA, M.L.; PALLESCHI, G. Carbon nanotube purification: Preparation and characterization of carbon nanotube paste electrodes. Anal. Chem., v.75, p.5413-5421, 2003.

WANG, J. (Ed.) Electroanalytical techniques in clinical chemistry and laboratory medicine, New York: VCH Publishers, 1996.

XU, M.T.; CHEN, L.F.; SONG, J.F. Polarographic behaviors of diclofenac sodium in the presence of dissolved oxygen and its analytical application. Anal. Biochem., v.329, p.2127, 2004.

YILMAZ, B. GC-MS determination of diclofenac in human plasma. Chromatographia, v.71, p.549-551, 2010.

Received for publication on $30^{\text {th }}$ January 2014 Accepted for publication on $25^{\text {th }}$ October 2014 